\title{
Study on Genetic Variability for Yield and Quality of Different Genotypes of Yard Longbean (Vigna unguiculata sub sp. sesquipedalis (L.) Verd.)
}

\author{
N. Savithiri ${ }^{1 *}$, A. Beaulah ${ }^{1}$, K. Shoba Thingalmaniyan ${ }^{1}$, \\ S. Rajeswari ${ }^{2}$ and Rakesh Kumar ${ }^{1}$
}
${ }^{1}$ Department of Vegetable Crops, Horticulture College and Research Institute, ${ }^{2}$ Centre for Plant Breeding and Genetics, Agriculture College and Research Institute, TNAU, Coimbatore-641003, India

*Corresponding author

\section{A B S T R A C T}

\begin{tabular}{|l|}
\hline Ke y w o r d s \\
$\begin{array}{l}\text { Yardlong bean, } \\
\text { Variability, Heritability, } \\
\text { Genetic advance }\end{array}$ \\
\hline Article Info \\
\hline $\begin{array}{l}\text { Accepted: } \\
\text { 24 July } 2018 \\
\text { Available Online: } \\
\text { 10 September } 2018\end{array}$ \\
\hline
\end{tabular}

Biometrical analysis of yield and its contributing characters was made for yard long bean with the use of sixty two genotypes. Phenotypic variation was greater than that of genotypic and environment variations for all the characters concerned. Minute differences between genotypic and phenotypic coefficient of variation indicated less environmental influences on considered characters. High heritability in broad sense and genetic advance estimated for the characters viz., plant height $(99.51 \%$ and $95.33 \%)$, pod yield per plant $(98.85 \%$ and $73.51 \%$ ), green pod length $(98.21 \%$ and $80.21 \%)$, green pod weight (98.73\% and $66.41 \%$ ), number of pods per plant $(95.89 \%$ and $63.48 \%$ ), number of pods per plot $(96.71 \%$ and $72.63 \%)$, estimated pod yield per hectare $(99.46 \%$ and $77.54 \%)$, crop duration (92.22\% and $21.86 \%$ ), ascorbic acid (98.82\% and $22.19 \%$ ), crude protein (98.84\% and 43.03$)$ and dry matter content $(98.16 \%$ and $22.11 \%)$.

\section{Introduction}

Yardlong bean (Vigna unguiculata sub sp. sesquipedalis) belongs to the family Fabaceae is an important leguminous vegetable crop, grown for its nutrient rich green pods and seeds. Yardlong bean is thought to have originated in Africa and spread to Indonesia, Thailand, Philippines, Taiwan and China. Yardlong bean is commonly known as string bean, long podded cowpea, asparagus bean, snake bean, Chinese long bean, pea bean, bora, bodi, kidney bean etc. It is a highly nutritive vegetable containing a good amount of digestible protein both in pods (23.5 26.3\%) and in leaves (Ano and Ubochi, 2008). The pods are also rich in vitamin A, riboflavin (0.09 mg), calcium (72 mg), phosphorus (59 $\mathrm{mg}$ ), sodium (4 mg), potassium, magnesium and vitamin C (Anonymous, 2006). Apart from that, they are good source of micronutrients containing iron (102.7 - 120 $\mathrm{mg})$, zinc $(32.6-36.7 \mathrm{mg})$, manganese $(2.9$ $3.3 \mathrm{mg})$ and cobalt $(0.3-0.6 \mathrm{mg}$ ) (Ano and Ubochi, 2008).

Although it is a highly nutritive summer vegetable, no commercial variety of yard 
longbean with high yield and better pod quality has been released in Tamil Nadu till now and no proper research thrust has been given for the improvement of this vegetable. The crop has remained unexploited owing to low productivity, long duration and indeterminate growth habit. The efforts of improving the crop by utilizing indigenous and exotic germplasm have been useful in breaking the yield barriers (Shivashankar and Kulkarni, 1989; Shivashankar et al., 1993). Considering the above facts the present investigation was undertaken to facilitate the development of genotypes for high yield and quality.

\section{Materials and Methods}

The materials for the study comprised of sixty genotypes (local genotypes and commercial varities) of yardlong bean. Local genotypes were collected from different regions of Kerala and Tamil Nadu. The experiment was carried out at the College Orchard, Department of Vegetable Crops, Horticultural College and Research Institute, Tamil Nadu Agricultural University, Coimbatore during 2016 - 2017, following randomized block design (RBD). Sowing done with spacing of $1.0 \mathrm{~m}$ between rows and $0.3 \mathrm{~m}$ between plants in a row. Plants were trailed on coir ropes tied between wooden stakes erected $1.0 \mathrm{~m}$ apart along rows of plants. Recommended doses of fertilizer, irrigation, weeding, mulching and other cultural practices were done as and when required.

Data were collected from five randomly selected plants from each plot and analyzed statistically. Genotypic and phenotypic variance was estimated according to Lush (1940) and genotypic and phenotypic coefficients of variations were estimated by Burton (1952). Heritability in broad sense was calculated by Lush (1940) and Robinson et al., (1949). The expected genetic advances for different characters and genetic advance expressed as percentage of mean were estimated by Johnson et al., (1955).

\section{Results and Discussion}

Genetic variability studies provide basic information regarding the genetic properties of the population based on which breeding methods are formulated for further improvement of the crop.

These studies are also helpful to know about the nature and extend of variability that can be attributed to different causes, sensitive nature of the crop to environmental influences, heritability of the characters and genetic advance that can be realized in practical breeding progress in any crop improvement venture depends mainly on the variability existing in the traits of the base population.

The relative magnitude of PCV per cent was higher than the corresponding GCV per cent for all the characters studied, which indicated that these characters are having interaction with environment to some extent (Ram and Singh, 1993). Presence of narrow gap between Phenotypic Coefficient of Variability (PCV) and Genotypic Coefficient of Variability (GCV) for all the characters under study, suggested that the traits studied have low environmental influence. In general, the Phenotypic Coefficient of Variation (PCV) was slightly higher than the corresponding Genotypic Coefficient of Variation (GCV) for all the characters, which indicated that environment also played a considerable role in expression of these characters which was also reported by Ali et al., (2005) in lablab, Golani et al., (2007) in hyacinth bean, Rai et al., (2008) in Indian bean and Chattopadhyay and Dutta (2010) in dolichos bean. There was a narrow disparity between PCV and GCV for all the characters indicating that selection for these characters would be effective. 
A better idea of relative amount of variation can be obtained by comparing the coefficient of phenotypic and genotypic variation of each character studied. The data revealed higher estimates of PCV than the corresponding estimates of GCV for different characters through the extent of difference between the two was relatively low. The traits like plant height, number of pods per plant, green pod length, green pod weight, green pod yield per plant, green pod yield per plot and estimated pod yield per hectare had high estimates of genotypic and phenotypic coefficient of variation. This indicated the maximum variability existing in the genotypes for these characters and offers good scope for improvement of these traits by simple selection. Similar findings were reported by Golani et al., (2007) in hyacinth bean and Mohan and Aghora (2002) in dolichos bean.

Moderate GCV and PCV was observed for number of primary branches, crop duration, ascorbic acid, crude protein and dry matter content whereas lowest GCV and PCV was observed for days to first flowering, days to 50 per cent flowering and crude fibre. Similar results were observed by Mahalingam et al., (2013) in dolichos bean and Pravin et al., (2013) in cowpea. These moderate and lowest GCV and PCV estimates for these traits revealed that the extent of response of these traits for selection would be lesser than that of the other traits.

Table.1 Estimates of variability and genetic parameters of yard long bean genotypes

\begin{tabular}{|c|c|c|c|c|c|c|c|c|}
\hline \multirow{2}{*}{$\begin{array}{c}\text { S. } \\
\text { No. }\end{array}$} & \multirow{2}{*}{ Characters } & \multirow{2}{*}{ Mean } & \multicolumn{2}{|c|}{ Range } & \multicolumn{2}{|c|}{ Variability (\%) } & \multirow{2}{*}{$\mathbf{h}^{2}(\%)$} & \multirow{2}{*}{$\begin{array}{l}\text { GA } \\
(\%)\end{array}$} \\
\hline & & & Min. & Max. & GCV & PCV & & \\
\hline 1. & Plant height $(\mathrm{cm})$ & 187.87 & 61.27 & 348.43 & 46.39 & 46.51 & 99.51 & 95.33 \\
\hline 2. & Number of primary branches & 5.57 & 4.00 & 7.30 & 10.68 & 13.28 & 64.66 & 17.68 \\
\hline 3. & Days to first flowering & 52.38 & 46.50 & 58.00 & 5.19 & 5.36 & 94.00 & 10.37 \\
\hline 4. & Days to 50 per cent flowering & 56.73 & 51.00 & 62.60 & 4.63 & 4.80 & 92.77 & 9.18 \\
\hline 5. & Number of pods per plant & 49.70 & 22.50 & 72.54 & 31.47 & 32.14 & 95.89 & 63.48 \\
\hline 6. & Green pod length $(\mathrm{cm})$ & 44.07 & 15.95 & 72.35 & 39.29 & 39.65 & 98.21 & 80.21 \\
\hline 7. & Green pod weight (g) & 22.56 & 10.67 & 35.05 & 32.44 & 32.65 & 98.73 & 66.41 \\
\hline 8. & Green pod yield per plant $(\mathrm{g})$ & 830.62 & 424.30 & 1512.24 & 35.89 & 36.10 & 98.85 & 73.51 \\
\hline 9. & Green pod yield per plot $(\mathrm{kg})$ & 7.58 & 3.82 & 14.11 & 35.85 & 36.46 & 96.71 & 72.63 \\
\hline 10. & Estimated pod yield per ha(t ha $\left.{ }^{-1}\right)$ & 23.36 & 11.71 & 42.28 & 37.74 & 37.84 & 99.46 & 77.54 \\
\hline 11. & Crop duration & 130.82 & 95.77 & 150.20 & 11.05 & 11.51 & 92.22 & 21.86 \\
\hline 12. & Ascorbic acid $\left(\mathrm{mg}^{\left.100 \mathrm{~g}^{-1}\right)}\right.$ & 12.96 & 10.19 & 15.79 & 10.84 & 10.90 & 98.82 & 22.19 \\
\hline 13. & Crude protein $(\%)$ & 19.68 & 13.04 & 24.86 & 16.61 & 16.71 & 98.84 & 34.03 \\
\hline 14. & Crude fibre (\%) & 3.22 & 2.67 & 3.66 & 6.99 & 7.81 & 80.14 & 12.89 \\
\hline 15. & Dry matter content $\left(\mathrm{g} \mathrm{plant}^{-1}\right)$ & 28.50 & 21.31 & 34.49 & 10.84 & 10.94 & 98.16 & 22.11 \\
\hline
\end{tabular}

Heritability and genetic advance as per cent of mean

Heritability of metric traits is of good significance for a plant breeder with which a genotype can be recognized by its phenotypic expression. The genetic variation along with the heritability estimates would give better idea about the expected efficiency of selection (Burton, 1952). A proper environment is needed for the gene to express the character. The relative influence of either the gene or environment over the variability of different characters in a population may vary widely. 
Hence, estimate of a portion of variability that is due to heredity (additive gene effect) from out of the observed variability (phenotypic variability) is most important for segregating material for selection. High heritability indicates that phenotype strongly reflects the genotype due to the genes desirable and transmits them to their off spring.

In the present study, the heritability values were quite high for all the characters, indicating that the major part of the variability was due to genotypic causes (Table 1). High heritability also indicated that there was more number of additive genes for these characters. The results are in line with the findings of Rai et al., (2008) and Chattopadhyay and Dutta (2010) in dolichos bean.

High heritability coupled with high genetic advance was observed for most of the traits viz., plant height, number of pods per plant, green pod length, green pod weight, green pod yield per plant, green pod yield per plot, estimated pod yield per hectare, crop duration, ascorbic acid, crude protein and dry matter content. This indicates that these characters can be improved directly through selection. This result is in conformity with the findings, for plant height Gnanesh et al., (2005) in lablab, Pravin et al., (2013) in cowpea and for number of pods per plant Mohamadali and Madalageri (2007) in winged bean, Mahalingam et al., (2013) in dolichos bean and Prasanth and Sreelatha (2014) in winged bean and for pod length Anandhi et al., 2007 in cluster bean and Mahalingam et al., (2013) in dolichos bean; for pod weight Mahalingam et al., (2013) in dolichosbean and Prasanth and Sreelatha (2014) in winged bean ; for yield per plant Prasanth and Sreelatha (2014) Mahalingam et al., (2013) in winged bean and Gnanesh et al., (2005) in lablab; for ascorbic acid Gnanesh et al., (2005) in lablab; for crude protein Mahalingam et al., (2013) in dolichos bean.
High heritability with moderate genetic advance was recorded for number of primary branches, days to first flowering and crude fibre. High heritability but moderate genetic advance, which confirms the predominance of additive and non-additive gene action. Similar results were conformity with the findings, for days to first flowering by Pravin et al., (2013) in cowpea; for days to 50 per cent flowering by Mahalingam et al., (2013) in dolichos bean; for crude fibre by Mahalingam et al., (2013) in dolichos bean.

\section{References}

Ali, F., B. Sikadar, A.K. Roy and O.I. Joarder. 2005. Correlation and genetic variation of twenty different genotypes of lablab bean (Lablab purpureus (L.) Sweet) Bangladesh J. Bot., 34(2): 125128.

Anandhi, K., K. Sunny and Oommen. 2007. Variability and heritability and heritability of yield and related characters in clusterbean (Cyamopsis tetragonoloba (L.) Taub). Legume Res., 30(4): 287-289.

Ano, A.O. and C.I. Ubochi. 2008. Nutrient composition of climbing and prostrate vegetable cowpea accessions. African J. Biotech., 7(20): 3795-3798.

Burton, G.W. 1952. Quantitative inheritance in grasses. Sixth international grassland Cong., 1: 277-283.

Chattopadhyay, A and S. Dutta. 2010. Characterization and identification of selection indices of pole type dolichos bean. Veg. Crops Res. Bulletin., 73: 3345.

Gnanesh, B.N. 2005.Genetic variability and divergence studies by $\mathrm{D}^{2}$ statistics and RAPD analysis in Field bean (Lablab purpureus L. Sweet). M. Sc. (Agri.) Thesis, Acharya N. G. Ranga Agril. Uni. S.V. Agri. College, Tirupati. 
Golani, I.J., D. R. Mehta and M.V. Naliyadhara. (2007). Genetic variability, correlation and path analysis for green pod yield and its characters in hyacinth bean. Orissa J. of Hort., 35(1): 71-75

Johnson, H.W., H.F. Robinson and R.E. Comstock. 1955. Estimates of genetic and environmental variability in soybeans. Agron. J., 47: 314-328.

Lush, J.L. 1940. Intra - sire correlation and regression of off spring on dams as a method of estimating heritability of characters. Proc. Amer. Soc. Animal Production, 33: 293-301.

Mahalingam, V., Mohammed Yassin and S. Ramesh Kumar. 2013. Genetic variability and character association in dolichos bean. SAARC J. Agrl., 11(2):161-171.

Mohamadali, A. and M. B. Madalageri. 2007. Analysis of genetic variability for seed yield and its component characters in Winged bean (Psophocarpus tetragonolobus (L.) Dc). Legume Res., 30(4): 290-291.

Prasanth, K. and I. Sreelatha kumary. 2014. Variability and heritability studies for pod yield and its component characters in winged bean [Psophocarpus tetragonolobus (L.)] An International Quaterly J. of Life Sci., 9(4): 17951797.

Pravinkumar, K. Nathishkumar, R. Muneeswari, Nagajotthi, T. Rajesh Lomrorand R.Usha Kumari.(2013). Morphological and genetic variation studies in cowpea genotypes (Vigna unguiculata $\mathrm{L}$. Walp.) Legume res., 36 (4): 351-354.

Rai, N., P.K. Singh, A. Verma, H. Lal, D.S. Yadav and M. Rai. 2008. Multivariate characterization of Indian bean (Lablab purpureus (L.) Sweet) genotypes. Ind. J. Pl. Genet. Res., 21(1): 42-45.

Robinson, H. F., R.E. Comstock and V. H. Harvery. 1949. Estimates of heritability and degree of dominance in corn. Agron. J., 41: 353-359.

Shivashankar, G. and R.S. Kulkarni. 1989. Field bean (Dolichos lablab L. varlignosus). Indian Hort., 34: 24-27.

Shivashankar, G., R.S. Kulkarni, H. E. Shashidhar and D. M. Mahishi. 1993. Improvement of field bean. Advances in Hort., 5: 277-286.

\section{How to cite this article:}

Savithiri, N., A. Beaulah, K. Shoba Thingalmaniyan, S. Rajeswari and Rakesh Kumar. 2018. Study on Genetic Variability for Yield and Quality of Different Genotypes of Yard Longbean (Vigna unguiculata sub sp. sesquipedalis (L.) Verd.). Int.J.Curr.Microbiol.App.Sci. 7(09): 3613-3617. doi: https://doi.org/10.20546/ijcmas.2018.709.448 